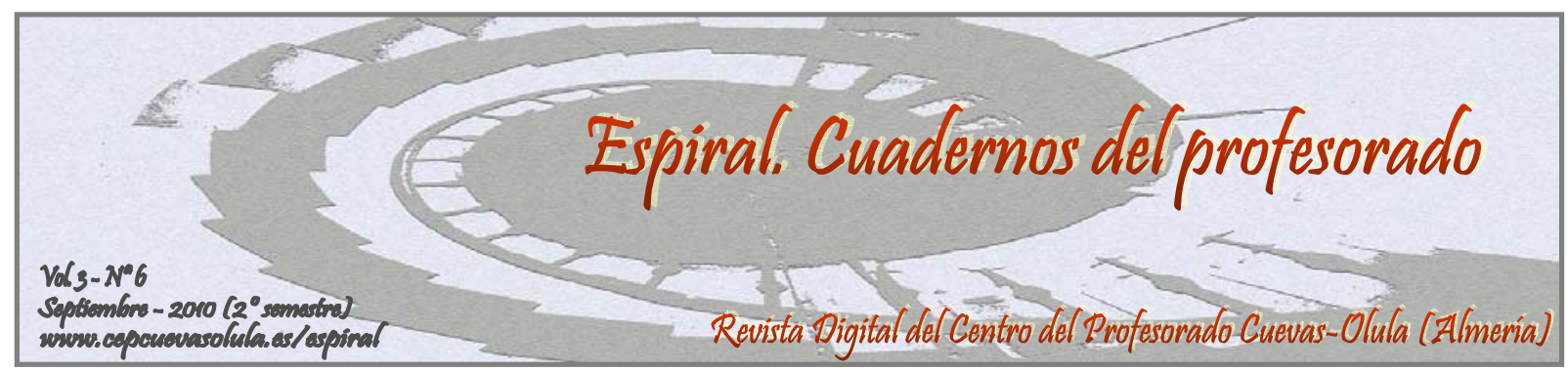

\title{
LA RENOVACIÓN DEL TEATRO ESPAÑOL EN EL ÚLTIMO TERCIO DEL SIGLO XX
}

\section{RENEWAL OF SPANISH THEATER IN THE LAST THIRD OF THE TWENTIETH CENTURY}

\author{
Khaled M. Abbas
}

\section{Facultad de Lenguas y Traducción, Universidad de Al-Azhar, Egipto; Facultad de Lenguas y Traducción, Universidad Rey Saúd, Arabia Saudí.}

RESUMEN: En los últimos treinta años del siglo XX, el teatro español ha experimentado un profundo proceso de renovación, tanto estilística como temática, que en parte se ha basado en un nuevo ambiente social y en una atención creciente del público. En el presente trabajo nos limitaremos a indagar tan sólo sobre algunos aspectos específicos así como la profundización en el contexto cultural del teatro de estos años; conocer las líneas maestras que rigen la trayectoria del teatro español desde las postrimerías del régimen de Franco hasta bien entrado el siglo XXI; la investigación en torno a algunos aspectos específicos de dicha trayectoria, con una especial mención de sus autores y obras; y poner de relieve la situación del teatro, ya sea público, ya privado, tanto en lo que atañe a su renovación, como a su evolución durante las últimas tres décadas del siglo XX. Analizaremos por tanto la trayectoria del teatro en el último tercio del siglo XX, con la intención de discernir si durante esa época la experimentación constante cristalizó en una renovación efectiva y duradera sobre la cual evolucionó el teatro de la España actual.

Palabras clave: teatro español, siglo XX, teatro independiente español, crítica teatral.

\begin{abstract}
In the last thirty years of the twentieth century, the Spanish theatre has undergone a deep process of renewal, both stylistic and thematic, which is partly based on a new social environment and an increasing public attention. In this paper we will investigate on just some specific aspects as well as deepening the cultural context of the drama of these years, know the guidelines that govern the trajectory of Spanish drama since the end of the Franco regime until the middle of the XXI century, the research into specific aspects of that history, with special mention of their authors and works, and highlight the situation of the theatre, whether public, private, both in terms of its renewal, and its evolution over the last three decades of the twentieth century. We hill analyze both the history of theatre in the last third of the twentieth century, aiming to discern if during that time constant experimentation crystallized in an effective and lasting renewal which evolved over the Spanish theatre nowadays.
\end{abstract}

Key words: Spanish drama, twentieth century, Spanish independent theatre, theatral criticism. 
Abbas, K. M. (2010). La renovación del teatro español en el último tercio del siglo XX. Espiral. Cuadernos del Profesorado [en línea], 3(6), 15-31. Disponible en: http://www.cepcuevasolula.es/espiral.

Fecha de recepción: 23/02/2010

Fecha de aceptación: 25/05/2010
Enviar correspondencia a: rimkhaled2001@yahoo.com

\section{1.- INTRODUCCIÓN.}

En el presente trabajo trataremos de demostrar cómo a lo largo de los últimos treinta años del siglo XX el teatro español ha experimentado un profundo proceso de renovación, tanto estilística como temática, que en parte se ha basado en un nuevo ambiente social y en una atención creciente del público.

Sin duda, resumir en pocas líneas un periodo tan denso en acontecimientos y cambios es una tarea compleja y hasta cierto punto peligrosa, no sólo a causa del amplio periodo de tiempo que se ha abarcado y de las dificultades que tal empeño implica, sino también porque ha sido preciso indagar en un tema muy amplio que transcurre durante una época cargada de sucesos trascendentales en la historia de España, los cuales no dejaron de repercutir sobre el teatro. Así pues, restringiremos nuestra exposición tan sólo a algunos aspectos específicos:

- La profundización en el contexto cultural del teatro de estos años.

- Conocer las líneas maestras que rigen la trayectoria del teatro español desde las postrimerías del régimen de Franco hasta bien entrado el siglo XXI.

- La investigación en torno a algunos aspectos específicos de dicha trayectoria, con una especial mención de sus autores y obras.

- La puesta en claro de la situación del teatro, ya sea público, ya privado, tanto en lo que atañe a su renovación, como a su evolución durante las últimas tres décadas del siglo XX: es decir, cómo el teatro dependiente ha recuperado progresivamente un lugar de privilegio y cómo el texto se ha convertido en la viga maestra del nuevo teatro español.

Se trata, en suma, de precisar qué se entiende cómo concepto de renovación, aplicado al teatro del período transitorio y de las dos décadas siguientes. Analizaremos por tanto la trayectoria del teatro en el último tercio del siglo XX, con la intención de discernir si durante esa época la experimentación constante cristalizó en una renovación efectiva y duradera sobre la cual evolucionó el teatro de la España actual.

Con esa finalidad, iniciaremos nuestro comentario sobre los acontecimientos teatrales más relevantes acaecidos en España durante la etapa previamente delimitada, los cuales, en nuestra opinión, influyeron profundamente en el desarrollo del panorama teatral español a lo largo de las décadas siguientes.

\section{2.- EL TEATRO ESPAÑOL DURANTE LOS ÚLTIMOS AÑOS DEL FRANQUISMO.}

Después de la Guerra Civil (1936 - 1939), los dramaturgos españoles se enfrentaron a una censura implacable que hacía difícil, sino imposible, ofrecer una visión crítica de la realidad. Desde el final del conflicto hasta los últimos años de la década de los 60 , el teatro español, en todas sus facetas, sufrió una profunda crisis existencial.

En esencia, predominaba el teatro comercial, pues no sólo las empresas eran privadas ${ }^{(1)}$ (con la repercusión que, puede presumirse, este hecho tuvo sobre el costo de las localidades), sino que el público era esencialmente burgués, amoldándose a sus gustos el quehacer teatral, ya en las formas, ya en el repertorio. En el Editorial del número extraordinario de la revista Cuadernos para el diálogo de junio de 1966 se escribía:

"El pueblo español no va al teatro, no le interesa el teatro, no ve en él un lugar que refleje sus inquietudes o dé acogida a sus problemas.” “... el teatro constituye hoy uno de los sectores más deprimidos dentro del contexto cultural español. (ello se debe sin duda a) la centralización, la insuficiente libertad, la carencia de sentido crítico, la discriminación de las otras culturas distintas a la imperante, las dificultades a los autores jóvenes y menos jóvenes 
que intentan plantear sus obras dentro de su perspectiva ideológica... ${ }^{(2)}$.”

En el mismo número, el crítico José María de Quinto apuntó lo siguiente:

“(El teatro español)... continúa viviendo de espaldas al pueblo, a la cultura, empeñado en halagar a los instintos de las clases acomodadas, tratando de enmascarar la realidad tras cortinas de incienso ${ }^{(3)}$."

Este panorama, sin embargo, no es tan tajante como dejan entrever los críticos, pues de él emergen dos figuras notables por su inteligencia teatral, aunque alejadas entre ellas por su percepción de la realidad. Nos referimos a Buero Vallejo y a Alfonso Sastre. El primero estrena, ya durante la era democrática (a partir de 1975) sus dos obras Jueces de la noche, (representada por primera vez en 1979) y El tragaluz: ambas fueron objeto de una excepcional acogida, quizá porque el teatro de Buero recoge de nuevo, expresándolas brillantemente, las inquietudes inherentes al espíritu humano, ahondando de nuevo en las paradojas y los límites de la libertad humana, de la soledad.... Por su parte, Sastre, un acérrimo comunista, no ha conseguido desligar su producción teatral de su obediencia política, y por esa causa concibe el teatro como un instrumento de acción supuestamente revolucionaria, dirigido contra el Franquismo, al cual no consiguió destruir, como pretendía, pues bajo esas premisas resultaba inaceptable para el Régimen, que lo sometió al más absoluto ostracismo. No obstante, gozó de algún renombre durante la era democrática, cuando estrenó Los últimos días de Enmanuel Kant contados por ETA Hoffmann (1990). Su gran éxito estuvo constituido por La taberna fantástica (1985), texto escrito en los sesenta. Esta pieza rezumaba neorrealismo, pero anticipaba también la búsqueda de la tragedia compleja. Desde hace algún tiempo, las extremosas opciones políticas manifestadas por Sastre han marginado a este dramaturgo ${ }^{(4)}$.

Estas dos figuras clave del periodo fueron seguidas por un enjambre de autores inconformistas que siguieron sus pasos, valiéndose también del realismo para recalcar su compromiso social. Dichos autores encuadraron la llamada Generación Realista, o Perdida, que surgió a fines de la década de los cincuenta; se trata de personajes tan influyentes como Martín Recuerda, Rodríguez Méndez, Lauro Olmo, José
María Buded o Carlos Muñiz. No son dramaturgos cuya creación se expusiera durante el Franquismo, porque eran tan críticos con el Régimen como enemigos del teatro comercial, $y$, por añadidura, resultaban muy antipáticos al público mayoritario, debido a su apego por el realismo social como forma de exponer la injusticia social.

Ahora bien, junto al realismo social, el lirismo también sienta plaza en el teatro español de los años sesenta del siglo $\mathrm{XX}$, cuando empiezan a escribir dos autores que suponen una alternativa de calidad al realismo. El primero es Antonio Gala, cuyas obras oscilan entre el lirismo y la reflexión moral, especialmente a partir de ciertos mitos literarios o bíblicos: ¿Por qué corres, Ulises? o Las cítaras colgadas de los árboles. De su obra en la democracia hablaremos más tarde con detalle. El segundo, Fernando Arrabal, relacionado con los movimientos de vanguardia surrealistas y postistas, se decanta decididamente por una absoluta renovación total del teatro (lo que él define como "teatro pánico") y manifiesta un agudísimo sentido crítico contra la burguesía y el Franquismo: no es pues extraño que apenas fueran representadas sus obras en España y que buscase el éxito allende las fronteras españolas, concretamente en Francia, donde alcanzó gran prestigio. Sus obras se centran obsesivamente en la incomunicación humana, la soledad y el exilio, la absurdidad de la guerra, el derrumbe de las estructuras cohesionadoras de la sociedad...

\section{3.- EL NUEVO TEATRO ESPAÑOL: LOS LLAMADOS "DRAMATURGOS SOTERRADOS”.}

Hacia la mitad de la década de los 60 del siglo $\mathrm{XX}$, es evidente el desgaste del realismo social y la búsqueda de nuevas formas de expresión dramática por parte de los autores españoles, -que se inspiraron en las grandes corrientes innovadoras del momento en el teatro europeo (el teatro del absurdo, Brecht, Artaud)-, que dio lugar a una nueva vanguardia teatral, denominada por los estudiosos "Nuevo Teatro Español”(5). Con ese nombre se designa a un grupo de dramaturgos jóvenes, poco conocidos todavía fuera del círculo de los expertos e iniciados, a pesar de que existen en torno a ellos algunos libros, artículos e incluso bibliografías recientes sobre el tema ${ }^{(6)}$, y a pesar de que menudearon los estrenos de sus obras, sobre todo durante los últimos años del régimen de Franco ${ }^{(7)}$. Su valor 
diferencial es el tratamiento formal: desechan el enfoque realista para sustituirlo por enfoques simbólicos o alegóricos. Recurren a la farsa, lo grotesco, las deformaciones esperpénticas y dan entrada a lo alucinante o lo onírico, valiéndose, entre otros recursos, del lenguaje, -tan directo como poético-, o de los recursos no verbales, plásticos, sonoros, etc.-. Por diversas razones, no han conseguido llegar al público teatral ni desarrollar una trayectoria regular y continuada, pues la mayor parte de estos autores mantuvieron una postura de oposición al régimen franquista, que les gratificó con una mayor presión de la censura y les hizo objeto de la represión policíaca $^{(8)}$. Estos dramaturgos fueron pues tan ignorados en su momento que incluso la crítica del momento no les prestó mayor atención ${ }^{(9)}$.

El tema central de este nuevo teatro es la crítica del sistema político y social del Franquismo, siquiera en la misma medida que el rechazo mostrado hacia el teatro comercial, así que no es extraño dichos autores fueran sistemáticamente ignorados hasta los años 80 , cuando ya la situación política y social se había modificado. Y aún puede considerarse dicha aceptación no fue tardía, puesto que el cambio político no llevaba el mismo ritmo que la modificación de los gustos culturales. De hecho, fueron reivindicados a partir de 1983, cuando se fundó el Centro de Documentación Teatral (CDT) que les permitió expresarse libremente. Desde sus orígenes, este teatro puso en uso fórmulas dramáticas que no gustaban ni a las compañías teatrales ni al auditorio mayoritario.

Entre los nuevos autores, algunos son coetáneos de los dramaturgos realistas (José Rubial, Francisco Nieva, Romero Esteo, etc.) y otros más jóvenes (Diego Salvador, Martínez Mediero, Alberto Miralles, etc.). Independientemente de su edad, todos ellos experimentaron enormes dificultades para ver representadas sus obras, que sólo vieron la luz pública a la sombra del llamado Teatro Independiente. No es pues extraño que algunos de sus autores más señeros hayan gozado tardíamente del éxito, como por ejemplo Martínez Mediero, Francisco Nieva o Alonso de Santos o lo hayan obtenido en el extranjero, como Fernando Arrabal.

Pero, ¿quiénes componen este nuevo grupo de autores teatrales? En primer lugar destaca José Ruibal, autor de una cierta calidad dramática y artífice de la palabra; no en vano, él mismo define su teatro como "verbo en movimiento". Comenzó a escribir en los años 50 del siglo XX, dando a las tablas Los mendigos (1957), donde presenta crudamente la miseria y su causa (que, según él, no sería sino la corrupción política). Durante el Franquismo, escribió otros textos importantes, aunque escasamente difundidos: $\mathrm{La}$ secretaria (1957), El padre, El Supergerente, (1968), Los ojos (1969) y La máquina de pedir (también de 1969): en todos ellos incide sobre la manipulación de la pobreza por quienes la causan. Sus personajes reflejan la opresión: ejecutivos, mujeres frívolas, educadores, políticos, especuladores... El hombre y la mosca fue representada en 1983 en el Teatro María Guerrero de Madrid: es un coloquio entre el Hombre y su Doble, que refleja la inconsistencia de la tiranía.

Es incuestionable el interés que presentan otros autores, como por ejemplo Luís Riaza, que se dio a conocer a finales de los sesenta con obras como Los muñecos (1968) o Las jaulas (1970). El desván de los machos y el sótano de las hembras (1974), El palacio de los monos (1977) o Retrato de dama con perrito (1979). Luís Riaza investiga sobre el verdadero significado de lo popular haciendo uso de una renovación formal y lingüística. Otros textos suyos son Retrato de un niño muerto (1984), El emperador de los helados (1986) y El buque (1988), obra con la cual obtuvo el primer premio en un certamen donde compitió con Rodrigo García, uno de los valores más sólidos de la generación que surge en los últimos años ochenta, quien presentó su obra Reloj. El cordobés Miguel Romero Esteo, en cuyo rico lenguaje contrastan cultismos y coloquialismos, presenta en Pizzicato irrisorio y gran pavana de lechuzos (1966) el descoyuntamiento de una familia convencional, cuyo hijo predica la revolución. En Fiestas gordas del vino y el tocino, representada en 1978, elabora un teatro de calle en el cual se unen personajes literarios y fantásticos. En 1983, alcanza gran éxito con Tartessos, "epopeya de la mítica ciudad prehistórica, dramatizada al estilo de las antiguas fiestas profanas ${ }^{(10),}$.

Manuel Martínez Mediero, por su parte, sigue una línea simbólica y humorística.

Las hermanas de Búfalo Bill (1974) se representaba el día en que murió Franco. Su Teatro antropofágico (1978) consta de tres obras breves: El convidado, El último gallinero y Las planchadoras. Es posible que El último gallinero sea su obra más característica. 
El catalán Alberto Miralles fundó el grupo Cátaro y escribió una obra significativa, El trino del diablo (1981), que puede considerarse, en esencia, como una variación sobre el mito de Fausto. La fiesta de los locos (1984) es un espectáculo musical ambientado en el Medievo, donde trata la muerte del Conde de Liaño, un extravagante fanático religioso descabezado en una bacanal. Cismaría especial para mujeres (1991), Manzanas azules, higos tristes (1995), son otras dos importantes obras de su teatro.

Otros autores forman parte de este grupo: Luis Matilla, Jerónimo López Mozo, José María Bellido, Carmen Resino, Antonio Martínez Ballesteros o Ángel García Pintado figuran entre los dramaturgos más destacados del Teatro Nuevo. La mayor parte de la producción de esos autores subterráneos o clandestinos, como suelen definirlos los críticos, nunca llegó a los escenarios, frustrándose así su capacidad para ser un revulsivo social y teatral en su contexto. La causa de su ausencia de las carteleras se debe, como se ha señalado antes, a su anti-franquismo militante. Una vez desaparecido el franquismo, sus textos perdieron gran parte de su aliciente y ya no poseyeron demasiado interés para el público.

Cabe decir que durante este periodo no faltaron los autores, sino sus representaciones. Ausentes de las carteleras teatrales, algunos de ellos se vieron obligados, de grado o por fuerza, a participar en el teatro "colectivo" y no "dependiente", donde se silencia el papel del dramaturgo y la teatralidad supera los valores literarios. Merece la pena centrarse sobre ese fenómeno teatral, a causa del papel que ha desempeñado en el teatro español antes y después de la transición, prácticamente hasta fines del siglo XX.

\section{4.- LA EVOLUCIÓN DEL TEATRO INDEPENDIENTE O COLECTIVO EN ESPAÑA DURANTE LA ÚLTIMA FASE DEL FRANQUISMO Y LA ERA DEMOCRÁTICA.}

Hacia finales de la década de los 60 del siglo XX, España vivió una apertura política e ideológica que influyó decisivamente en la actividad teatral. El teatro llamado "dependiente", deja de ser la única opción para un público cuya ideología se está modificando perceptiblemente, que es más inquieto y se muestra ávido de nuevas formas de expresión. Junto a los teatros oficiales se formarán pues "nuevas compañías de teatro que intentaron imponer un teatro alternativo en todos los sentidos ${ }^{(11)}$.".

Fruto de este ambiente fue la aparición del Teatro Independiente, tan importante en el contexto teatral de la época. Era eminentemente joven $\mathrm{y}$, por tanto, inconformista, tanto en su pensamiento político como social, y conscientemente trataba de ser anti-convencional: "la importancia del movimiento del Teatro Independiente en los últimos años del régimen de Franco radica en que representa una alternativa potencial en el sistema de teatro oficial y en que sus pocas puestas en escena se convirtieron en el símbolo de un movimiento de protesta antifranquista y vivo.”, apunta Wilfried Floeck $^{(12)}$.

Los jóvenes autores de la época, sin embargo, no cesaron de ser molestados por la censura $^{(13)}$, aunque ésta ya no mostraba los mismos reflejos de otrora y se produjeron algunos estrenos muy vanguardistas en cuanto a forma y lenguaje, e incluso se publicaron algunas de sus obras, aunque eso sí, en tiradas muy reducidas ${ }^{(14)}$.

El Teatro Independiente, -que fue uno de los fenómenos más sugestivos de la escena durante el franquismo e incluso durante la Transición-, transformó paulatinamente el panorama teatral español a partir de la segunda mitad de los años sesenta del siglo pasado. Procede del teatro de cámara y ensayo ${ }^{(15)}$, -propio de los aficionados o semi-profesionales y de los teatros universitarios estudiantiles, que o bien se iban distanciando cada vez más del régimen o bien se habían creado al margen de la actividad teatral oficial-, y lograron granjearse un sólido respaldo intelectual debido a su apoyo por parte del público eminentemente universitario.

Las compañías de Teatro Independiente cabe decir que la mayoría actuaban en solitariopropagaban una nueva concepción teatral aspirando de forma creciente a la profesionalización y su estilo teatral se integra en las nuevas formas del teatro de vanguardia.

Este modelo teatral se halla abocado a la búsqueda de nuevos lenguajes que se apartan conscientemente del texto escrito, obligando al teatro subvencionado, universitario, etc., a adecuarse a una nueva concepción del espectáculo centrado en la imagen y en el cuerpo del actor $\mathrm{y}$ en sus posibilidades expresivas, espectáculo cada vez más multidisciplinar, escogido y metateatral ${ }^{(16)}$. 
Ese nuevo teatro se caracteriza en igual medida por la expresividad que imprime al actor, mediante el uso de la pantomima, entre otros recursos no menos inusuales, como por la espectacularidad de los montajes, cuyos autores no vacilan en servirse de las más diversas influencias, como por ejemplo los elementos propios de la fiesta popular, mezclados con trucos pirotécnicos o con el empleo de muñecos gigantes, zancos, etc. ${ }^{(17)}$.

Las reivindicaciones económicas pasan a constituir un tema central en esta fase, pues sus componentes aspiran sin ambages a obtener la estabilidad, en el transcurso de la década de los 70. Se constituye así, en 1976, la Asamblea de Teatro Independiente Profesional, compuesta por 33 grupos cuyo propósito común es difundir las innovaciones mediante festivales ${ }^{(18)}$ y encuentros nacionales, valiéndose para ese fin de dos salas estables (Cadarso en Madrid y Villarroel en Barcelona). En 1977, la estadística de los logros del teatro independiente, en tan sólo diez años, es reveladora: “... 33 estrenos anuales, más de 3.000 representaciones, más de medio millón de espectadores y $700.000 \mathrm{kms}$. recorridos... ${ }^{(19), "}$.

Ruiz Ramón hace un censo y habla aproximadamente de 150 compañías integrantes de este movimiento en toda España en la primera mitad de los años setenta ${ }^{(20)}$. Notable en este contexto es el hecho de que el Teatro Independiente no surge como un fenómeno aislado ni restringido sólo a la capital, sino que aparece de forma simultánea en otras regiones o ciudades como Gijón, Murcia, Valladolid, Oviedo, Alicante, Zaragoza, Barcelona, Madrid, Cádiz, Córdoba y muchas otras; en todo caso, dichas compañías asumen constantemente su vocación de vanguardia. Aquí Mencionaremos solamente aquellas que destacaron especialmente por su producción:

- El Teatro Experimental Independiente (TEI) (1960), Madrid.

- Los Goliardos (1964), Madrid.

- Tábano (1968), Madrid.

- La Escola d'Arte Dramatic Adrriá Gual (1960), Barcelona.

- Los Cátaro (1966), Barcelona.

- Els Comediants (1977), Barcelona.

- Els Joglars (1962), Barcelona.

Existen otros grupos que aparecieron en provincias, de los cuales hacemos mención de:
- El Teatro Estudio lebrijano (1966).

- El Teatro Universitario de Murcia (1967).

- La Cuadra (1972).

Junto a las diferencias ideológicas y estéticas que se aprecian entre las diferentes compañías, se perciben también algunos rasgos comunes del movimiento, definidos en fecha muy temprana por el manifiesto de Los Goliardos, publicado en Primer Acto (núm. 121, 1967, pp. 9-12), bajo el título de "Hacia el Teatro Independiente (27 notas anárquicas a la caza de un concepto)". Dichos rasgos son:

- La oposición ideológica frente al Estado de Franco.

- El rechazo del teatro comercial.

- La propagación de un teatro de crítica social.

- La oposición al teatro burgués convencional y con ella la difusión de un teatro popular y la búsqueda de público nuevo.

- La búsqueda de posibilidades de expresión nuevas y de innovaciones estéticas, tomando en consideración la teoría y la práctica internacionales correspondientes.

- El rechazo del teatro de autor y de teatro literario y con ello la preferencia por un teatro de director y la consolidación de signos teatrales no lingüísticos.

- La búsqueda de lugares nuevos, no convencionales.

- La aspiración a la descentralización del trabajo teatral.

- La aspiración a la profesionalización del teatro ${ }^{(21)}$.

La producción de los grupos de Teatro Independiente fue marginal bajo el régimen franquista, debido a las persecuciones e impedimentos continuos por parte de la policía y de las autoridades competentes. Son muy pocas las obras que llegaron a los escenarios $u$ obtuvieron algún éxito de público. El grupo Tábano (fundado en 1968), por ejemplo, estrenó el 21 de junio de 1970 una pieza muy significativa: Castañuela 70, una crítica lúcida mediante la cual se satiriza tanto a los censores como a quienes promueven su actividad. Fue prohibida después de obtenido un éxito extraordinario, convirtiéndose en el referente 
histórico de toda una generación ${ }^{(22)}$, de tal modo que la década de los 80 del siglo $\mathrm{XX}$ se caracteriza por sus innovaciones escénicas ${ }^{(23)}$. El rasgo distintivo del Teatro Independiente español durante este periodo es la consolidación de los nuevos lenguajes escénicos que han comenzado a vislumbrarse en los últimos años del franquismo. Grupos como Els Joglars, Els Comediants, Dagoll Dagom de Cataluña o La cuadra de Sevilla, surgidos en los últimos años de la dictadura, van a ejercer un gran impacto en el conjunto del movimiento teatral.

En definitiva, el Teatro Independiente desempeñó un papel destacado en la historia del teatro español. El dramaturgo y director de escena José Luis Alonso de Santos, que contribuyó personalmente a la producción de este movimiento, llegó a afirmar que:

“(el)...Teatro Independiente pasará a la historia del teatro español del siglo $X X$ como una de las aportaciones más vigorosas, originales e influyentes de la época. Y esto no sólo porque muchos de sus componentes son hoy nombres destacados en el panorama teatral español, y porque dicho movimiento, aunque con otras formulaciones, fruto de la diferente situación, ha encontrado una especie de continuidad que se manifiesta en la existencia de grupos y formas alternativas de producción en torno a las cuales se mueve hoy una buena parte de los elementos más inquietos y renovadores de la escena actual $^{(24)}$.”.

Entre las obras más significativas del Teatro Independiente destacan no sólo Castañuela 70, de Juan Maragallo y el grupo Tábano-, sino también El retablo del flautista (1970), de Jordi Teixidor, Quejío (1972), de La cuadra de Sevilla y El bebé furioso (1974) y Las hermanas de Búfalo Bill (1975), del escritor pacense Manuel Martínez Mediero. Hubo otras obras que tuvieron así mismo una excelente acogida, pero en circuitos más reducidos o limitados, como por ejemplo La guerra y el hombre (1967), de Alberto Miralles, Oratorio (1968), de Jiménez Romero, La familia (1973), de Pérez Casaux, El Fernando (1972) del Teatro universitario de Murcia y La torna (1977), que criticaba la justicia y la pena de muerte; ésta última, por cierto, fue denunciada por las Fuerzas Armadas españolas. A finales del siglo XX, el grupo Els Joglars desarrolla un humor ácido y satírico en obras como Ubú president, -sátira de Jordi Pujol, o Dalí. Els Comediants destacaron con Sol solet (1978), el viaje fantástico de unos cómicos a la utopía del Padre Sol.

El asentamiento político de la democracia restó argumentos a los grupos independientes, los cuales comenzaron a perder vigor y presencia en la escena española. Tan sólo unos pocos han subsistido $\mathrm{y}$ han podido mantener una continuidad: se cuentan entre ellos los montajes siempre polémicos y provocadores de Els Joglars, (fundado y dirigido por Albert Boadella), un grupo de éxito internacional, Els Comediants, La Cubana o La Fura dels Baus; éstos últimos reivindican un teatro festivo, de grandes máscaras, de gigantes y cabezudos, de espacios abiertos, un teatro que entronca con el folclore y las fiestas populares; en sus montajes se subvierten todos los supuestos de la representación teatral, empezando por el espacio del público, constantemente violentado por la acción.

En definitiva, la trayectoria escénica del Teatro Independiente siguió siendo incierta, a pesar del predicamento del cual gozara en su momento, y finalmente perdió el encanto que pudiera otorgarle la clandestinidad. La voluntad de reflejar la realidad socio-política imperante va cediendo paso a experimentos formales cada vez más esteticistas en los últimos años 80 . La actividad de sus componentes se vio reducida, a la vez que el teatro empieza a dejar de ser vehículo de contestación política directa:

"Así, muchos de los antiguos grupos (Tábano, Goliardos, TEI, Teatro Libre...) se van disolviendo, y los nuevos que surgen traen otros planteamientos en los que prima más lo estrictamente artístico, excepto en lugares como el País Vasco, en permanente estado de crispación política, o Cataluña y Galicia, donde el factor lingüístico y la nacionalidad son objetivos de reivindicación unificadores $^{(25)}$."

Al mismo tiempo, su auditorio, que en los años 60 del siglo $\mathrm{XX}$ era eminentemente estudiantil, va menguando a medida que se incorpora a la vida profesional y se aburguesa. Además, “...la nueva libertad acabó con la mayor parte de los grupos independientes, desasistidos de público ${ }^{(26)}$ ”. 
5.- EL TEATRO EN LA ERA DEMOCRÁTICA. (EL AUGE DEL TEATRO PÚBLICO Y EL REGRESO AL TEATRO DE AUTOR).

El advenimiento de la democracia, en 1975, vino precedido por una época de incertidumbre y aprensión:

"El fin de la dictadura en 1975 señala el comienzo de una época de euforia como de aprensión ${ }^{(27)}$.”.

El teatro, como otros fenómenos de la vida española, experimentaba cierta aprensión y no mostró inmediatamente las profundas transformaciones que había experimentado en los años previos al fallecimiento de Francisco Franco, a pesar de que:

"La llegada de la democracia había despertado amplias y esperanzadas expectativas en el ámbito teatral español, tanto tiempo amordazado por la censura, que ponía trabas al autor para expresarse, al productor para sufragar el espectáculo, al actor para manifestarse en libertad y al público para conocer lo que sus artistas querían decirle desde la escena ${ }^{(28)}$ ".

Sin embargo, al cabo de algún tiempo, el panorama teatral español recuperó obras y autores hasta entonces prohibidos por la censura y se revitalizó la actividad de ciertos grupos de teatro independiente, al tiempo que continuaban estrenando con cierta regularidad autores como Antonio Gala, Jaime Salom o Juan José Alonso Millán, verdaderos herederos del teatro convencional, al seguir la línea de Benavente o Pemán. Alonso Millán, por ejemplo, fue calificado por César Oliva de "...último bastión de la comedia convencional ${ }^{(29), "}$. Ese autor comenzó su labor teatral en el teatro universitario, una de las escuelas más fecundas del teatro en la segunda mitad del siglo. Poco a poco, Alonso Millán se decantó por el género de la comedia, en la estela del vodevil o el vodevil negro, o de la farsa que fantasea con asuntos de actualidad. Esos dramaturgos, en resumen, estrenaron sus obras con regularidad, y su obra no se halla exenta de calidad artística, literaria y teatral, pero su éxito no redunda en modo alguno en una transformación de la escena española. Quizá sea por las siguientes razones:

- Falta de infraestructura.
- Carencia de compromiso por parte del Estado $^{(30)}$.

- La crisis económica mundial.

Esa crisis del teatro se prolongó hasta 1982, paliándose merced a notables cambios estructurales, muchos de los cuales agilizaron la actividad teatral. Son éstos:

- En 1978, se fundó el Ministerio de Cultura.

- En 1980, se reinauguró el Teatro Español -cerrado desde su incendio en 1975- como teatro municipal.

- En 1983, se estableció un Centro de Documentación Teatral (CDT).

- En 1983, se crea la Compañía Nacional de Teatro Clásico, bajo la dirección de Adolfo Marsillach.

La creación de los centros estatales de teatro aparejó la consolidación del teatro público, así como la recuperación paulatina del papel y el prestigio del autor. Además, se fomentó un ambicioso plan de descentralización teatral, muy positiva para fomentar la producción escénica. En ese contexto, se emprendieron algunas actividades dirigidas a estimular la creación teatral en provincias, aparte de Madrid y Barcelona. Esa política se apoyó tanto en las Comunidades Autónomas como en las Diputaciones o los Ayuntamientos. La normativa se inspiraba en los siguientes principios:

- La instalación de centros teatrales en las Comunidades Autónomas.

- La restauración de antiguos teatros.

- El fomento de festivales teatrales por toda la Nación.

La política de descentralización tuvo muchas consecuencias positivas para el desarrollo de la actividad teatral, aunque, en verdad, Madrid y Barcelona siguen siendo, como antes, las únicas ciudades con una oferta teatral regular $y$ abundante $^{(31)}$. Aún así, el teatro público pudo considerarse realmente consolidado. En cambio, las compañías privadas iniciaron una retirada paulatina de la escena, pues eran incapaces de competir económicamente con las salas públicas (subvencionadas). Por tanto, en España el teatro privado sigue padeciendo serios problemas de liquidez e incluso de supervivencia.

Aunque en España el Ministerio de Cultura se inauguró en 1978, fue realmente a partir de 1983 cuando su política cultural comenzó a 
ofrecer algunos resultados positivos, y no sólo por lo que al teatro se refiere. La producción teatral llegó a ser en verdad muy abundante, sin desdecir de la calidad, aunque algunos críticos e historiadores del teatro español disienten en este último punto. Es el caso de Alberto Fernández Torres, quien, por ejemplo, opina que:

"La transformación del teatro sólo se ha llevado a cabo en la superficie ${ }^{(32)}$.".

Tampoco Moisés Pérez Coterillo se siente optimista por la situación del teatro en la democracia pues, según él:

"La ilusión del cambio y la modernización de la escena española que se suscitan a comienzos de los ochenta no son hoy más que pura decepción y escepticismo ${ }^{(33)}$.".

En definitiva, un importante sector de la crítica teatral y de los dramaturgos, -figuras tan relevantes como García Lorenzo, Andrés Amorós, Alonso de Santos, Sanchís Sinisterra-, mostraba una preocupación creciente por la superficialidad del fenómeno, que no aparejó una renovación en profundidad; además, en cualquier caso, siempre hubo serios problemas para editar la producción. En consecuencia, durante muchos años el problema no radicó tan sólo en la aparición de autores, sino en la representación de su producción, pues la carencia de medios repercutió ineluctablemente en la marginalización del teatro en general. El panorama generó al fin algunos resquemores entre los profesionales, que mostraban su desconfianza por la intervención del Estado en un medio que, por naturaleza, es anticonformista.

Aún así, el Estado no sólo no cesó nunca de intervenir en la actividad teatral $\mathrm{y}$, por el contrario, intervino cada vez en mayor medida, ya sea en el fomento propiamente dicho de la actividad, ya en los aportes económicos, ya en respaldo administrativo. Baste saber a este respecto que en 1980, en España, había únicamente un centro dramático, (dirigido en un principio por Adolfo Marsillach, con sede en el teatro María Guerrero), y un teatro municipal (el Teatro Español, dependiente del Ayuntamiento de Madrid) y que el presupuesto dedicado por las administraciones al teatro era de 200 millones de pesetas. Pero en 1992 había 18 teatros públicos, es decir centros de producción, en Valencia, en Galicia, en Extremadura, en Castilla León, en Cataluña, etc., y el dinero dedicado al teatro en este año pasaba de dieciocho mil millones de pesetas. Como se ve la diferencia es muy notable y grande.

En conclusión, la libertad política, la abolición de la censura y la intervención del Estado han sido positivas en los siguientes aspectos $^{(34)}$ :

- En primer lugar, la intervención del Estado ha facilitado (por medio de los centros de producción, de los conciertos con las compañas privadas y del sistema de subvenciones públicas del control administrativo) la puesta en escena de excelentes espectáculos de teatro, los cuales ninguna compañía privada habría podido afrontar. El dinero público ha permitido contemplar excelentes piezas: Se han representado obras como las Comedias bárbaras, Voces de Gesta y Martes de Carnaval de Valle Inclán u obras de Lorca como El público, El maleficio de la mariposa, Bodas de Sangre, o La casa de Bernarda Alba. Asimismo, se adaptaron con enorme éxito algunas novelas de Miguel Delibes, como por ejemplo Cinco horas con Mario (1979), Las guerras de nuestros antepasados (1989).

- En segundo lugar, esta intervención ha proporcionado trabajo a los profesionales, sometidos hasta entonces a una situación de paro sempiterno.

- En tercer lugar, el sistema de subvenciones ha incrementado el número de espectadores, estable hasta 1994.

- En cuarto lugar, se han podido organizar montajes extraordinariamente complejos, como: El Jardín de los cerezos de A. Chejov, Enrique IV de L. Pirandello o La loca de Chaillot de J. Giraudoux.

- En quinto lugar, los festivales internacionales, (como el renovado Festival de Otoño de Madrid), permitieron contemplar grandes espectáculos. El público ha vuelto a ver así obras consagradas de todos los tiempos, o adaptaciones de otros géneros, tales que el Mahabaratta, Hamlet o Titus Andronicus de Shakespeare y Misterio bufo de Darío Fo.

- En sexto lugar, se han reestrenado tragedias y comedias clásicas como Edipo, rey de Sófocles o Anfitrión de Plauto, y algunas piezas relevantes del teatro clásico español, como El alcalde de Zalamea o 
La dama duende de Calderón, El caballero de Olmedo o Porfiar hasta morir de Lope de Vega, La Celestina de Fernando de Rojas, El burlador de Sevilla o El vergonzoso en Palacio, Don Gil de las calzas verdes de Tirso de Molina, No puede ser... el guardar una mujer, de Agustín de Moreto, La malquerida de Benavente, La venganza de don Mendo de Muñoz Seca o Luces de Bohemia de Valle Inclán ${ }^{(35)}$. La revitalización de los clásicos del teatro nacional del Siglo de Oro fue un punto de partida muy positivo para el desarrollo del teatro español en la democracia. Es que antes y "a pesar de poseer un inmenso fondo de piezas de teatro clásico y de la reputación internacional de la comedia del Siglo de Oro, no había cristalizado en España una tradición continua en la puesta en escena de estas piezas. No había siquiera apenas actores que estuvieran en disposición de recitar las comedias en verso de la época barroca adecuadamente ${ }^{(36)}$.”. El interés por el teatro clásico provocó que en 1986 se fundara en la Compañía Nacional de Teatro Clásico, cuyo objetivo se centró en colmar ese vacío: "Las nuevas versiones de nuestro teatro del siglo de oro tuvieron una permanencia asegurada en los escenarios españoles desde la creación de la Compañía Nacional de Teatro Clásico...(37)". Por tanto, el montaje de obras clásicas o universales fue un paso decisivo para restañar algunas carencias materiales padecidas por el teatro español, ya en plena democracia. Teniendo en cuenta los altos costos del teatro clásico, las subvenciones estatales han hecho posible la realización de brillantes montajes que de otra forma difícilmente podrían haberse llevado a cabo.

- En séptimo lugar, se ha emprendido la tarea de elaborar talleres de iniciación a la formación de actores, de escritura escénica, etc. ${ }^{(38)}$, y se ha fomentado su actividad con la creación de premios, como el de textos teatrales "Marqués de Bradomín"; las obras ganadoras y finalistas tienen desde entonces garantizada la publicación y en gran medida su representación, mediante la cooperación con festivales de teatro y otras actividades.
El establecimiento de la democracia, no obstante, ha aparejado una nueva concepción teatral de la temática, más acorde, supuestamente, con los nuevos tiempos, ya sean alusiones sexuales explícitas, ya la homosexualidad o la droga, por ejemplo. Por supuesto, al lado de estas obras de carácter presumiblemente trascendental han aparecido también piezas más inclinadas a la crítica social, habitualmente muy irónicas ${ }^{(39)}$. En definitiva, se trata de obras que intentan responder a los nuevos valores de la vida española actual ${ }^{(40)}$.

Otro fenómeno muy llamativo del teatro en la democracia es la consolidación del teatro de autor, a pesar de la subsistencia del teatro colectivo, cuyo fuego sagrado aún mantenían algunos grupos de Teatro Independiente. Muchos son los dramaturgos que lograron estrenar en los años posteriores a la transición, y eso no supone que las obras estrenadas eran en su totalidad de menos calidad, pues durante el período de la transición se dieron a conocer una serie de dramaturgos que viven actualmente su apogeo. En un trabajo de las características del presente, sólo podríamos mencionar a unos pocos, entre muchos autores buenos.

Todavía resulta muy aventurado centrarse sobre sus características, porque la mayoría de ellos siguen en activo. Rodrigo García, uno de los dramaturgos más importantes de la joven escena española, muestra un rechazo contundente a cualquier intento de clasificación al decir:

"Tendré que decirlo de una vez: odio las tendencias, no hacen más que reducir y el arte debe ampliar ${ }^{(4)),}$.

Muchos otros se han negado así mismo a establecer cualquier género de catalogación, por ser ésta una labor que, como mínimo, sería prematura, si no estéril. Aún así, y asumiendo el riesgo de lo absurdo de tal tentativa, es preciso realizar algún esbozo de clasificación, con el fin de estudiar y analizar la obra ya producida y de ofrecer una visión de conjunto de la misma. Emplearemos un criterio muy sumario, basado en su temática. En nuestra opinión, éstas son las tendencias esenciales:

1. Los autores que comenzaron a producir durante la dictadura franquista son tanto realistas como convencionales. En cuanto atañe al llamado teatro social, la mayor parte de sus producciones se han estrenado tan sólo a partir de 1975, cuando ya el interés del público ha decaído notablemente, a causa de la desaparición del contexto 
político. De todos ellos, sólo Buero Vallejo, aureolado de un éxito cierto y del respeto del público, ha podido estrenar obras de forma regular y otros, menos afortunados, sólo han podido estrenar sus obras de manera ocasional, como Martín Recuerda, Rodríguez Buded, Rodríguez Méndez y Sastre.

En lo que respecta al teatro convencional, son figuras señeras del mismo Jaime Salom o Juan José Alonso Millán, que prosiguen produciendo en la democracia, sin menoscabo de su éxito. Jaime Salom trata con preferencia la crítica a la burguesía y en esa línea estrena en 1976 La piel de limón, pieza en la cual "aboga por el divorcio desde un punto de vista que adopta alguna de las coordenadas del feminismo del momento ${ }^{(42)}$,". A esta obra siguen otras, como Una hora sin televisión, (1987), Mariposas negras (1994), etc. Alonso Millán es ya un escritor teatral consolidado y veterano, autor de más de ochenta obras, algunas de las cuales han merecido el elogio de la crítica y, muchas, el del público. En la democracia, logra gran éxito también con El camino verde y Capullito de alhelí ambas de 1985, Cuéntalo tú que tienes más gracia (1989) o Sólo para parejas (1995). Por último, pero no menos importante, mencionaremos a Antonio Gala, heredero de la larga tradición que emana de Jacinto Benavente y de Alejando Casona, aunque "en los inicios de su obra más bien parecía seguir la trayectoria de Antonio Buero Vallejo $^{(43)}$.". Gala es un ejemplo paradigmático de las dificultades que ofrece todo intento prematuro de clasificación, pues si con frecuencia se centra preferentemente en el teatro tradicional, sin embargo algunas de sus obras no pueden, en puridad, catalogarse en ese tipo de teatro: es el caso, por ejemplo, de ¿Porqué corres, Ulises? (1975), o de su llamada trilogía de la libertad: Petra Regalada (1980), La vieja señorita del paraíso, (1980) y El cementerio de los pájaros (1982). Después de esta trilogía, Antonio Gala ha dedicado la mayor parte de sus afanes a la novela, campo en el cual ha obtenido muchos laureles, pero sin embargo no ha renunciado a sus orígenes, como demuestran Samarkanda (1985) o El hotelito (1985), "una historia española en la que el autor pretende que nos riamos de nuestra propia sombra y al mismo tiempo se reflexione sobre nuestras propias fronteras interiores ${ }^{(44),} \mathrm{y}$ Séneca o el beneficio de la duda (1987), títulos todos que han gozado de los parabienes del público y del rechazo frecuente de la crítica.
2. El segundo grupo lo forman los llamados autores marginados o soterrados de los últimos años del franquismo. A partir de 1975, sus textos empiezan a lograr grandes éxitos. Se aproximan a la experiencia teatral con claras intenciones innovadoras. Estaban decididos a buscar una nueva forma dramática que sea expresión de un nuevo orden social. Autores procedentes en su mayoría de grupos de Teatro Independiente o universitario, utilizan fórmulas dramáticas innovadoras, aunque a veces recurren a otras formas tradicionales (la farsa, el sainete...) para abordar los problemas sociales contemporáneos (violencia, paro, droga, marginación, sexo, etc.). Parte de su famosa producción escénica ha sido llevada al cine gracias a los triunfos alcanzados en el teatro. En los últimos años de los 60 , su situación es aún más triste que el grupo anterior, salvo en algunos casos señalados, como el de de Manuel Martínez Mediero, cuyas obras albergan temas de carácter universal. Son autores característicos de este grupo Francisco Nieva, Luis Riaza, Hermógenes Sainz y Juan Antonio Castro, que siguen marginados del escenario a pesar de su continua producción. Aunque fuese conocido en el mundo teatral como escenógrafo, Francisco Nieva no llevó una obra suya a los escenarios hasta 1975 (escribe desde 1952). Se aproxima al teatro del absurdo, buscando el espectáculo. Con La carroza de plomo candente (1971), y El combate de Opalos y Tasia (1953), crea el llamado teatro furioso. Además, en una segunda línea, escribe un teatro de farsa y calamidad: Funeral y pasacalle, La señora Tártara o Coronada y el Toro (1986). El buscón 1975) y La paz (1977) son ejemplos característicos de esta su tendencia.

En este grupo, el valenciano José Sanchis Sinisterra es uno de los autores más críticos con la historia de España o su tradición literaria, de la que extrae las más sugestivas consecuencias, pues combina con habilidad la reflexión teatral con la erudición, en obras como Ñaque (1980), para recrear escenas y situaciones del teatro de los Siglos de Oro. Su obra más famosa es $i A y$, Carmela! (1987), ambientada en 1938. En iAy, Carmela! -afirma Gonzalo Pérez Olaguer, al final de la edición de Manuel Aznar Soler de Ñaque; ¡Ay, Carmela!-, que hay una "implacable reflexión política desprovista de acidez ${ }^{(45)}$.”;

Otro de sus representantes más notables es Fermín Cabal, que evoluciona desde el naturalismo costumbrista hasta formas mucho más avanzadas de ese propio realismo. Destacan entre sus creaciones iTú estás loco, Brionesi (1978), iEsta 
noche, gran velada! (1983), -que trata las miserias del boxeo-, o Caballitos del diablo (1985), donde denuncia el mundo de la droga. Castillos en el aire (1995) recrea la corrupción de la izquierda española en el poder; José Luis Alonso de Santos destaca por la creación de una comedia costumbrista, pero enraizada en los problemas sociales del presente, y con una ingeniosa utilización del lenguaje popular. De su producción sobresalen obras como iViva el Duque, nuestro dueño!, representada por el Teatro Libre e Independiente, el 9 de diciembre de 1975, El álbum familiar (1982), -drama simbólico que recuerda un viaje familiar en tren-, o La estanquera de Vallecas (1981). Su mayor éxito fue Bajarse al moro (1985).

Cabe recordar, dentro de ese grupo, a Domingo Miras, autor que no sólo maneja fluidamente la lengua española, sino que además demuestra una abierta admiración por los clásicos literarios españoles. Escribió dramas como Las brujas de Barahona (1978) o Las alumbradas de la Encantación Benita (1986), etc. En definitiva, "tanto individual como colectivamente, la obra de estos dramaturgos [...] se dirige hacia una ampliación de lo que entendemos por arte escénico, superando el tradicional objetivo realista por abarcar la experiencia dramática desde una multiplicidad de perspectivas sin denegar el elemento social y político ${ }^{(46)}$."

Josep María Benet i Jornet, Luis Matilla, Jerónimo López Mozo, Ignacio Amestoy, son otros autores que alcanzaron gran éxito en la democracia. Ofrecieron propuestas alternativas al teatro convencional y a su público, atentando contra las limitaciones del género y dotando a sus obras de una carga crítica indirecta, ya fuera valiéndose de la parodia, los juegos lingüísticos o las situaciones absurdas.

3. Por último, el tercer grupo los componen un grupo de jóvenes autores, nacidos entre los años 50 y 60 y madurados en la democracia. Casi todos han recibido un permio o un accésit del "Premio Marqués de Bradomín" para autores dramáticos en la categoría "menos de 30 años". Por esa razón, se les denomina a menudo como la “Generación de Bradomín”"(47). A pesar de la actividad estatal, los componentes de este grupo han experimentado serias dificultades para ver representadas sus obras. Los dramaturgos jóvenes reivindican la importancia del texto, frente al papel predominante del director teatral. Los planteamientos innovadores que realizan, rompiendo las estructuras dramáticas tradicionales, distorsionando el lenguaje y el orden lógico de la trama, han sido difíciles de digerir para una porción importante del público, que ha abandonado el teatro en beneficio de otros medios o espectáculos más generalistas (el cine, la televisión, los acontecimientos deportivos...). No es pues extraño leer esa afirmación de Sergi Belbel, autor y director teatral: "si se suprimiera el teatro muy pocos lo lamentarían. No así como el fútbol ${ }^{(48), ”}$. El alemán Wilfried Floek cree que la experiencia cultural común de ciertos autores está marcada por "la pérdida de confianza en las utopías políticas, las soluciones totalitarias de los problemas sociales, el reconocimiento logocentrista de la realidad, la constitución de sentido coherente, así como en la capacidad del idioma para lograr una reproducción objetiva de la realidad ${ }^{(49)}$.".

Sólo podemos mencionar aquí a algunos de esos dramaturgos jóvenes, entre los que se cuentan Paloma Pedrero, (artífice de un teatro breve que expone con gracia problemas de la condición femenina de tipo afectivo, sexual o social), que alcanza gran lirismo en obras como Una estrella (1990), (donde trata el desencuentro entre una hija y su difunto padre), el madrileño Ignacio García May, autor de Alesio, una comedia de tiempos pasados (1987), (premio Tirso de Molina de 1986) o Los vivos y los muertos (2000), (este texto refleja la violencia entre adolescentes) y Sergi Belbel, autor de Tálem (1989), Después de la Lluvia (1993), La Sangre (201), (se centra sobre el terrorismo) y Caricias (1991) (acerca de la violencia). Éste último autor escribió originalmente en catalán. Rodrigo García, por su parte, escribe obras muy interesantes, de concepción muy próxima a las artes plásticas: entre sus primeros espectáculos podemos mencionar Macbeth Imágenes, (accésit Bradomín 1985), Notas de cocina (1988), Acera derecha y Matando horas ambas de 1991 o After sun (2000). Yolanda Pallín, -cuyas obras están estructuradas en su mayoría de manera similar-, escribió en 1994 La lista negra, (acerca de la violencia entre grupos sociales) y Juan Mayorga ${ }^{(50)}$, -quien trata también en sus textos temas similares o existenciales-, como en Cartas de amor a Stalin (1999) o El traductor de Blumenberg (1999), pieza que se inscribe en una línea de teatro de tesis y que aborda el tema de los totalitarismos. No podemos olvidar a otros muchos, como Luisa Cunillé, Fernández Lera, Ignacio del Moral, Alfonso Armada, Ernesto Caballero, Juan Ramón Fernández, Antonio 
Álamo, Antonio Onetti, Sara Molina, Iziar Pascual ${ }^{(51)}$.

En definitiva, los escenarios españoles han vivido una actividad extraordinaria y arrojan un balance positivo, en el cual no han faltado ni las tendencias más en boga dentro de Europa ni las novedades más audaces. En este punto, las voces más autorizadas se muestran conformes. Dice García Templado:

"La creación dramática siguió las directrices señaladas a partir de la desaparición de la censura, y amplió su temática $^{(52)}$.”.

Y César Oliva:

"Se presenta con los perfiles más innovadores de los últimos tiempos ${ }^{(53)}$."

El propio crítico murciano vuelve a afirmar que:

"Los últimos cinco años -se refiere a los últimos 5 años desde la publicación de su trabajo- han supuesto la mayor renovación del teatro español desde la mitad del siglo XX. Nunca como ahorasigue Oliva- se advierte con mayor incidencia un cambio en la concepción de las formas escénicas... (54),".

Está claro que la experiencia democrática española, sobre todo a partir de 1982, supuso no sólo una auténtica renovación en el campo de las artes escénicas, sino también la rehabilitación y el desarrollo de la infraestructura física del teatro por todo el territorio español y una creciente disponibilidad de medios económicos.

\section{6.- CONCLUSIONES.}

La instauración de la democracia parlamentaria (1975) ha supuesto en España la aparición de un nuevo contexto en el cual el teatro ha encontrado un medio más favorable, en general, a su difusión. Sus posibilidades se han incrementado a medida que la Constitución Española de 1978 garantizó el nuevo sistema de gobierno y que el ingreso en la Unión Europea no sólo consolidó la estabilidad política, sino que además fomentó poderosamente la expansión de la cultura española.

En resumen, el panorama teatral de finales del siglo XX asistió a algunos cambios que podríamos condensar en los siguientes puntos:

- La abolición de la censura estatal y eclesiástica (para los textos de carácter no re- ligioso), que ha propiciado una gran vitalidad creadora entre los autores.

- El enorme aumento de las subvenciones del Estado.

- El establecimiento de un sistema teatral público, ya en cuanto respecta a la ampliación cuantitativa y regional de la oferta de edificios para el teatro y centros de producción (por ejemplo, la creación de la Compañía Nacional de Teatro Clásico y del Centro Nacional de Nuevas Tendencias Escénicas -lamentablemente desaparecido-, del Centro Dramático Nacional, del Teatro Nacional de Cataluña, de la Ciudad del Teatro de Barcelona y de otros muchos vinculados a los gobiernos autonómicos o locales), ya en cuanto atañe a la puesta en marcha de un Plan Nacional de Auditorios y Teatros, que persigue ofrecer más plazas de teatro en un gran número de ciudades, fuera mediante la recuperación de viejos teatros, fuera mediante la construcción de otros nuevos. Asimismo, se potencian los festivales dramáticos, se mejoran las condiciones de producción y se intenta recuperar a los espectadores defraudados en los años de la Transición, ofreciendo una oferta diversificada.

- La desaparición de la llamada Generación Realista en las carteleras habituales.

- La aparición de un nutrido grupo de autores jóvenes, de muy diversos estilos y tendencias, unidos por el denominador común de una especial inclinación al teatro de texto.

- El regreso al teatro de autor o de texto, así como la retirada paulatina del Teatro Independiente de los escenarios.

Es obvio que en la ejecutoria del teatro español, desde 1975, el contexto social ha ejercido una influencia nada despreciable. Así, por ejemplo, durante los primeros años de la democracia, surgieron por doquiera las representaciones de autores de gran calidad, cuyas obras, hasta entonces, habían sufrido un relativo ostracismo, y no sólo por causas políticas: es el caso de Valle Inclán, García Lorca, Max Aub o Alberti. Pero también se produjo un fenómeno de más bajo perfil, pues algunos sectores del público se dieron a espectáculos más groseros apelando a una 
sedicente libertad: de esa forma, proliferaron en los escenarios los desnudos femeninos más o menos justificados y otras actuaciones más o menos inmorales. Esta bulimia pornográfica fue de escasa duración y decayó rápidamente, desapareciendo en el momento en que la sociedad se apercibió de que en lo sucesivo, estos espectáculos no generarían mayores polémicas ni serían prohibidos, pues se nutrían tan sólo del morbo que genera la prohibición. Mayor importancia, en todo caso, merecen autores como Buero Vallejo, Antonio Gala o Jaime Salom, que pudieron desde entonces estrenar con regularidad.

Uno de los rasgos más relevantes del teatro de este periodo es la búsqueda de nuevos públicos y la recuperación de cuantos se vieron decepcionados por el teatro demasiado vanguardista. Dicha labor, sin embargo, se ve sometida a demasiados imponderables como para poder ser analizada en un trabajo de objetivos limitados, como el presente. Sin duda, uno de los mayores aciertos de esta etapa ha sido la revitalización del gran teatro clásico español del Siglo de Oro.

A finales del siglo $\mathrm{XX}$, siguen en activo los siguientes autores:

1.- Los que ya escribían durante la Dictadura Franquista sin demasiadas posibilidades de gozar de la representación pública de sus obras, a los cuales ya mencionáramos en páginas precedentes: Antonio Gala, Fernando Arrabal, Francisco Nieva, Buero Vallejo, Alfonso Sastre, Antonio Gala, Jaime Salom, Juan José Alonso Millán, etc. De los dramaturgos realistas, sólo Buero Vallejo pudo estrenar obras de una forma regular, aunque, como dijimos, autores como Martín Recuerda, Rodríguez Buded, Rodríguez Méndez y Sastre se han representado con menos frecuencia.

2.- Los llamados autores marginados o soterrados, procedentes de los últimos años del franquismo. Son autores confesadamente innovadores, cuya producción se dio a conocer a finales de la Dictadura, alcanzando grandes éxitos a partir de 1975. Se aproximan a la experiencia teatral con claras intenciones de renovación, buscando nuevas fórmulas dramáticas que correspondan a un nuevo orden social, cuya formación pretenden incitar. Como ejemplos representativos de este grupo destacan: José Sanchis Sinisterra, Fermín Cabal, José Luis
Alonso de Santos, Paloma Pedrero y Domingo Miras, etc.

3.- Los Dramaturgos de finales del siglo XX son el grupo más joven, pues está formado por escritores nacidos entre los años 50 y 60, cuya juventud transcurrió durante la era democrática. Los componentes de este grupo reivindican la importancia del texto, frente al papel predominante del director teatral. De este grupo merecen ser mencionados: Sergi Belbel, Luisa Cunillé, Rodrigo García, Alfonso Armada, Ernesto Caballero, Antonio Álamo, Antonio Onetti y Sara Molina, entre otros muchos.

Estos autores desarrollan una temática claramente alejada de cuanto se escribiera en décadas anteriores, amoldada claramente a los nuevos cambios políticos y estatales. No es pues extraño que, con relativa frecuencia, se aborden sobre las tablas algunos temas antaño considerados inconfesables, ya sean sexuales o de otro género. Junto a esas obras, pervive una tendencia crítica respecto a la burguesía, frecuentemente teñida de ironía y humor, y los temas más vodevilescos.

En este panorama relativamente esperanzador han surgido algunos interrogantes de cierta entidad: por ejemplo, ¿hasta qué punto puede resultar perjudicada la vocación crítica del teatro cuando su representación se basa en las ayudas del Estado? Desde ese punto de vista, ¿cómo puede evitarse que las decisiones personalistas dañen la trayectoria de unos u otros autores o impulsen la de otros? En todo caso, es indudable que toda subvención acarrea una pérdida de libertad.

Además, desde un punto de vista estrictamente técnico, los nuevos planteamientos dramáticos ponen en evidencia el conflicto permanente entre autor y director. En los años setenta y ochenta los directores de escena obtuvieron la hegemonía, pero los dramaturgos han recuperado su papel en décadas posteriores.

No es menos serio el evidente menoscabo que han padecido las compañías privadas, al fin y al cabo esqueleto real del teatro como negocio, y por tanto pieza esencial de su supervivencia. Las compañías privadas se han retraído o simplemente han desaparecido, a causa de la abusiva competencia del Estado, dotado de mayores capitales, redundando este hecho en la degradación del teatro concebido como espectáculo y por tanto como medio de influencia social. En este último aspecto, el teatro ha 
perdido una gran parte de su predicamento, porque muchos espectadores han dejado de acudir al teatro, desilusionados por la dudosa calidad y el talante ideológico de la oferta imperante a partir de la desaparición del Franquismo, y presumiblemente se han dado a otros medios de entretenimiento masivos (televisión, cine, conciertos, acontecimientos deportivos...)

En definitiva, se puede decir que, por muchas razones, el teatro en España se ha transformado profundamente durante los últimos treinta años. Durante esa etapa, los criterios de interpretación, el papel de la dirección de escena, los sistemas de producción, distribución y gestión, los gustos y expectativas del público, el papel de la crítica y los medios de comunicación, y, por supuesto, la propia escritura dramática han evolucionado rápidamente.

\section{7.- NOTAL AL PIE.}

(1) En la España franquista, y a diferencia de lo ocurrido en otros países europeos, el estado no consideraba el teatro un bien cultural público que debe fomentar y apoyar. Por ello, no apareció, hasta finales de los años setenta, un sistema teatral público subvencionado por la Administración digno de mención. Cf. Floeck, Wilfried, "El teatro español contemporáneo (1939-1993). Una aproximación panorámica”, en AA.VV. (1995): Teatro español contemporáneo: Autores y tendencias, Kassel, Reichenberger, (p. 3).

(2) Cuadernos para el diálogo, (junio de 1966): número extraordinario, (pp. 3-4).

(3) Ibíd., (p. 27).

(4) Véase Oliva, César (2004): La última escena. Teatro español de 1975 a nuestros días, Madrid, Cátedra, (pp. 33 y ss.).

(5) Dichos dramaturgos comienzan a expresarse hacia 1965, aunque hay quien remonta sus primeras actividades a los primeros años 70. En 1965, el crítico e historiador norteamericano Goerge E. Wellwarth inició una serie de estudios que habían de concluir en su libro Spanish Underground Drama (Teatro Español Subterráneo) aparecido en 1972, (publicado en español en 1978). Este libro se centraba en los autores teatrales marginados en España. Wellwarth, profesor de la Universidad Estatal de Nueva York, en Binghamton, ha dado a conocer en diferentes estudios monográficos y antologías el Nuevo Teatro Español como fenómeno de la más reciente creación dramática española. Véase Pörtl, Klaus (1985): "El Nuevo teatro español. La crítica del sistema político y social en Antonio Martínez Ballesteros y Miguel Romero Esteo", en Anales de Literatura Española, no 4, (p. 363); y Sanz Villanueva, Santos (1994): Historia de la
Literatura Española, 6/2, $5^{\mathrm{a}}$ edición, Barcelona: Ariel, (p. 422).

(6) Parte de su producción será difundida en revistas como Pipirijaina o Primer acto y en editoriales como La avispa.

(7) Véase Pörtl, Klaus: "El Nuevo teatro español...", artículo citado, (p. 363).

(8) Cf. Sanz Villanueva, Santos: Historia de la Literatura Española, op. cit., (pp. 421-432).

(9) Sin embargo, los críticos españoles empiezan a interesarse por la producción de estos dramaturgos sobre todo después del famoso estudio de George E. Wellwarth, Spanish Underground Drama.

${ }^{(10)}$ Ragué-Arias, María José (1966): El teatro de fin de milenio. (De 1975 hasta hoy), Barcelona, Ariel, (p. 63).

(11) Floeck, Wilfried: "El teatro español contemporáneo...”, op. cit., (p. 3).

(12) Ibíd.: (p. 5).

(13) Algunos de estos dramaturgos semi-anónimos, como suele llamarlos Alonso de Santos, empezaron a ser realmente conocidos hacia finales de los años 70 , consolidándose su trabajo personal en los 80 .

(14) Fernández-Torres, Alberto (coordinador) (1987): Documentos sobre el Teatro Independiente español, Madrid, CNNTE, (p. 11).

(15) Sin embargo, Santos Sanz Villanueva cree que la aparición del teatro independiente se ofrecía como una superación del teatro de cámara y ensayo, y como una alternativa a los viejos profesionales. En Historia de la Literatura Española..., op. cit., (p. 423). Los Teatros de Cámara y Ensayo, bajo cuyo alero se experimenta en la década de los 60, los teatros universitarios, dedicados al montaje de obras clásicas españolas y grupos aficionados de procedencia diversa de tendencia innovadora constituyen las diferentes fuentes de las que se nutre el teatro independiente. $C f$. Fernández-Torres, Alberto (coordinador): Documentos sobre el teatro..., op. cit., (p. 17).

${ }^{(16)}$ Se reduce la importancia del trabajo individual y se revaloriza el teatro como labor de conjunto. Consideración del texto como apoyo del espectáculo y no viceversa. Entonces la colectividad es uno de los rasgos fundamentales de este nuevo teatro. Eso significa que en el Teatro Independiente el término "autor" gozaba en algunos de estos grupos de un notable desprestigio: primaba la creación colectiva, los espectáculos creados a partir de improvisaciones en torno a un determinado tema, o los textos refundidos. En Festivales como el del Sitges o Salas como la de Cadarso, etc., se dieron a conocer autores como Romero Esteo, Domingo Miras, Luis Riaza, Nieva, Martínez Mediero, Ballesteros, Alfonso Jiménez Romero, Perez Casaux, Ruibal, Matilla, López Mozo, y otros muchos. Ciertos dramaturgos como Alonso de Santos, al igual que muchos de sus 
compañeros, tuvo que asumir, durante sus quince años en el Teatro Independiente, las diversas tareas de actor, director, autor, técnico, tramoyista, promotor, escenógrafo y cada una de las mil actividades que implica el montaje de un espectáculo, desde el momento de su concepción hasta el de su representación. Véase Alonso de Santos, José Luis (Abril, 1989): "Principio y fin del Teatro Independiente", en Campus digital (publicaciones de la Universidad de Murcia), núm. 31. Revista online: http://www.um.es/campusdigital/index.html

(17) Cf. Lagos de Kassai, María Soledad: "Nuevos lenguajes escénicos en el teatro chileno de creación colectiva y en el teatro español de vanguardia”, en: AA.VV. (1994), De Lope de Vega a Roberto Cossa, Teatro español, iberoamericano y argentino, Osvaldo Pellettierri (editor), Buenos Aires, ( p. 159).

(18) Se potencian los festivales dramáticos: Almagro (teatro clásico español), Mérida (teatro grecolatino), Sitges (teatro de vanguardia), etc.

(19) Fernández-Torres, Alberto: Documentos..., op. cit., (p. 331).

(20) Ruiz Ramón, F. (1997): Historia del teatro español. Siglo XX. $11^{\text {a }}$ ed., Madrid, Cátedra, (p. 45)

(21) Para mayor información sobre las características del Teatro Independiente véase también FernándezTorres, Alberto: Documentos..., (pp. 83-86).

(22) Véase Sánchez Sánchez, Juan Pedro (2008): “Tábano y "Castañuela" 70: un hito del teatro popular de los 70”, Per Abbat. Boletín filológico de actualización académica y didáctica, núm. 6. (pp. 141-160).

(23) Véase Ruiz Ramón, F.: Historia del teatro español..., op. cit., (pp. 459-460).

(24) “Principio y fin del Teatro Independiente”, artículo citado.

(25) Véase Ibíd.

(26) Monleón, José (1955): “El teatro del consenso”, en AA. VV., Del Franquismo a la Posmodernidad. Cultura española (1975 - 1990), Madrid, Akal, (p. 243).

(27) Leonard, Candyce y John P. Gabriele (1996): Panorámica del teatro español actual, Madrid, Fundamentos, (p. 7).

(28) De Paco, Mariano: "El Teatro Español en la Transición: ¿Una Generación Olvidada?”, en Anales de Literatura Española, núm. 17, (p. 145).

(29) En Ragué-Arias, María José: El teatro de fin de milenio..., op. cit., (p. 97).

(30) La vida cultural no representó, en los primeros años de la democracia, una prioridad para el Estado, sin embargo, más tarde, como veremos, se harán muchos esfuerzos para que todo vuelva a la normalidad y que salga el teatro de su crisis imperante.
(31) Cf. Floeck, Wilfried: "El teatro español contemporáneo..., (pp. 12-14).

(32) Ibíd.: (p. 14).

(33) Ibíd.: (pp. 14-15).

(34) Para mayor información consúltese las siguientes referencias bibliográficas: Ruiz Ramón, F.: Historia del teatro español..., op. cit.; Toro, Alfonso, y Floeck, Wilfried: "El teatro español contemporáneo.... op. cit.; y Fernández-Torres, Alberto: Documentos sobre el teatro... op. cit.

(35) Véase García Templado, José (1992): El teatro español actual, Madrid, Anaya, (pp. 86-87).

(36) Floeck, Wilfried: "El teatro español contemporáneo..., op. cit., (pp. 8-9).

(37) García Templado, José: El teatro español actual, op. cit., (p. 86).

(38) También se han multiplicado y han mejorado las condiciones de las escuelas y las enseñanzas dedicadas a formar a los profesionales del teatro, se han establecido nuevos planes de estudio y nuevas especialidades, se ha organizado una eficiente Asociación de Directores de Escena y otras organizaciones profesionales, se han abierto perspectivas para el estudio de las materias propiamente teatrales, etc. En ese sentido, se ha dignificado la presencia del teatro en la sociedad.

(39) Entre los ejemplos notables de esa crítica social citamos los títulos siguientes: Los ochenta son nuestros (1988), de Ana Diosdado; Una hora sin televisión, 1998, de Jaime Salom; Noche de amor efímero, (1990), de Paloma Pedrero; y Alta seducción, 1989, de Manuela Reina.

(40) Cf. Leonard, Candyce y John P. Gabriele: Panorámica del teatro..., op. cit., pp. 7-8.

(41) Véase Floek, Wilfried (2004): "El teatro actual en España y Portugal en el contexto de la posmodernidad”, en Iberoamericana, IV, 14, (p. 47).

(42) Ragué-Arias, María José: El teatro de fin de milenio..., op. cit., (p. 102).

(43) Ibíd., (p. 99).

(44) Torres, Rosana: “Antonio Gala estrena en Madrid 'El hotelito', una reflexión sobre las fronteras interiores”, en El País, 12/12/1985.

(45) Sanchis Sinisterra, José (1991): Ñaque, ¡Ay, Carmela!, Madrid, Cátedra, (p. 304). Edición de Manuel Aznar Soler.

(46) Leonard, Candyce y John P. Gabriele: Panorámica del teatro..., op. cit., (p. 11).

(47) Véase Floek, Wilfried: "El teatro actual en España y Portugal...”, artículo citado, (p. 48).

(48) En Ragué-Arias, María José: El teatro de fin de milenio..., op. cit., (p. 114).

(49) “El teatro actual en España y Portugal...”, artículo citado, p. 49. 
${ }^{(50)}$ Este dramaturgo ha obtenido en 2009 el prestigioso premio de teatro Valle Inclán por su obra Paz perpetua.

(51) Véase Oliva, César: La última escena..., op. cit., (pp. 38 y ss.).

(52) García Templado, José: El teatro español actual, op. cit., (p. 87).

(53) Véase Oliva, César (1998): "Panorama General del Teatro Español en la década de los Noventa”, en AA.VV., La dramaturgia en Iberoamérica: Teoría y práctica teatral, Buenos Aires, Galerna, Getea-CITTI, (p. 131)

(54) Ibíd.: (p. 131). 